J. Clin. Chem. Clin. Biochem.

Vol. 28, 1990, pp. $149-153$

(C) 1990 Walter de Gruyter \& Co. Berlin - New York

\title{
Determination of Cathepsins B and H in Sera and Synovial Fluids of Patients with Different Joint Diseases
}

\author{
Dušica Gabrijelčič ${ }^{1}$, Anthony Annan-Prah ${ }^{1}$, Branka Rodičc ${ }^{1}$, Blaž Rozman $^{2}$, Vladimir Cotič ${ }^{1}$ and Vito Turk ${ }^{1}$ \\ ${ }^{1}$ Department of Biochemistry, J. Stefan Institute, Ljubljana, Yugoslavia \\ ${ }^{2}$ Rheumatology Clinic, The University Clinical Center, Ljubljana, Yugoslavia
}

(Received April 11/June 23/October 16, 1989)

Summary: Synovial fluids and sera of patients with inflammatory and metabolic joint diseases contain different cysteine proteinases. The quantities of cathepsins $\mathrm{B}$ and $\mathrm{H}$ were determined by newly developed specific enzyme-linked immunoassay tests (ELISA), with detection limits of $0.5 \mu \mathrm{g} / 1$ for cathepsin B and $3 \mu \mathrm{g} / 1$ for cathepsin $H$. The values of cathepsin B in normal sera ranged from $0.6 \mu \mathrm{g} / 1$ to $2 \mu \mathrm{g} / \mathrm{l}$, whereas in sera of patients with joint diseases they ranged from $1.7 \mu \mathrm{g} / 1$ to $18 \mu \mathrm{g} / \mathrm{l}$. Cathepsin $\mathrm{H}$ was not found in sera (values below $3 \mu \mathrm{g} / \mathrm{l}$ ), but was measurable in patients' synovial fluids. Patients with rheumatoid arthritis have on average the highest values of cathepsin B in synovial fluids, whereas patients with undifferentiated arthritis have the highest values of cathepsin $H$. The results show that cathepsins $B$ and $H$ are present in arthritic synovial fluids, where they may be implicated in destructive processes. There is as yet no clear correlation between the quantity of each cathepsin released in synovia and the clinical diagnosis or the stage of the disease.

\section{Introduction}

Lysosomal cysteine proteinases, e. g. cathepsins B and $\mathrm{H}$, play an important role in the degradation of intracellular tissue proteins (1). It has been suggested that their extracellular activity contributes to many pathological processes such as: inflammation, tumour growth and metastasis, demyelinating diseases, and cartilage destruction in rheumatoid arthritis or muscle dystrophy (2). It has been demonstrated, using radioimmunoassay and enzyme activity assay (3), that cathepsin B is secreted from rheumatoid synovial cells into the synovial fluid, indicating that the secreted form of cathepsin B expresses enzyme activity for a limited period. Once released and active, it may be involved in the degradation of connective tissue proteins; that cathepsin $B$ is able to degrade various connective tissue components in vitro, has been demonstrated for: proteoglycans (4), bovine collagen (5) and fibronectin (6).
In this paper ELISA tests are described for quantification of cathepsins $\mathrm{B}$ and $\mathrm{H}$ in control sera and in sera and synovial fluids of patients with different joint diseases. Moreover, we have shown that cathepsin B, determined immunologically in synovial fluid, is complexed with certain proteins, one of which is kininogen.

\section{Materials and Methods}

\section{Cạthepsins}

Cathepsin B was isolated from human liver as described by Zvonar (7). Cathepsin $\mathrm{H}$ was purified from human kidney according to Popovič (8).

\section{Samples}

Normal sera were obtained from the Blood Transfusion Centre, Ljubljana, Yugoslavia. Blood samples and synovial fluids of different joint diseases were supplied by the Rheumatology Clinic of the University Clinical Centre, Ljubljana. Yugoslavia. 
Twenty one patients were included in the study. The diagnosis of rheumatoid arthritis was defined according to the American Rheumatism Association criteria (9). Seronegative spondylarthritis, gout, pseudogout and osteoarthritis were diagnosed by usual laboratory and X-ray criteria. Undifferentiated arthritis was diagnosed in patients not meeting the above diagnostic criteria. Their synovial fluid contained more than $0.5 \mathrm{~g} / 1$ leukocytes, predominantly polymorphonucleocytes (10). In every patient, the degree of inflammation was characterized by sedimentation rate. The synovial fluid was aspirated from knee joints without the use of a local anaesthetic. The samples were divided into two parts; one was used for determination of the leukocyte count and differential cell count, the other was immediately centrifuged for $10 \mathrm{~min}$ at $10^{\circ} \mathrm{C}$ and $500 \mathrm{~g}$ in a Sorvall centrifuge and the supernatant frozen at $-20^{\circ} \mathrm{C}$.

\section{Electrophoresis}

SDS-PAGE was performed according to the method of Laemmli (11), on $40-300 \mathrm{~g} / 1$ polyacrylamide gels. Pharmacia kits were used with molecular weight standards (Pharmacia, Uppsala, Sweden).

\section{Preparation of polyclonal antibodies}

Immunization was carried out according to the procedure described by Morton (12). Cathepsins B and $\mathrm{H}$ were dissolved in $0.1 \mathrm{ml}$ phosphate-buffered saline, diluted with $0.1 \mathrm{ml}$ Freund's complete adjuvant in a final concentration of $0.6 \mathrm{~g} / 1$, and inoculated into a lymph node of a female New Zealand rabbit. Two $0.015 \mathrm{mg}$ booster doses were administered intracutaneously after 30 and 37 days. Blood samples were taken for the determination of the antibody titres. The animals were bled 10 days after the last injection, when the titre had reached a dilution of $1: 100000$. Sera were prepared by centrifugation $(1500 \mathrm{~g}$ for 15 $\min$ at $+4{ }^{\circ} \mathrm{C}$ ). The sera were kept frozen at $-20^{\circ} \mathrm{C}$ until use. Sheep antiserum against cathepsin B was kindly provided by Dr. P. Scheuber, Munich, FRG. Antibodies against cathepsin $\mathrm{H}$ were purified from rabbit antiserum by Protein A-Sepharose (Pharmacia, Uppsala, Sweden) as described by Ey (13). Antibodies against human kininogen were purified from rabbit antiserum, using the same procedure.

Immunoselective anti-cathepsin B antibodies were purified from rabbit antiserum by use of an immunoadsorbent column containing human liver cathepsin $\mathrm{B}$ linked to $\mathrm{CNBr}$-activated $\mathrm{Se}$ pharose 4B.

\section{Western blot analysis}

The specificity of eluted antibodies was tested by Western blot analysis. In the immunoblotting procedure pure cathepsin B and $\mathrm{H}$ were electrophoretically transferred to nitrocellulose filters (Schleicher \& Schüll BA85, Dassel, FRG) by the procedure of Towbin (14). Immunological detection of antigens was performed with antibodies against cathepsins $\mathrm{B}$ and $\mathrm{H}$ in a concentration of $10 \mathrm{mg} / \mathrm{l}$. After the incubation with peroxidaseconjugated goat anti-rabbit IgG (Jackson Immuno Research, Avondale, $\mathrm{Pa}$., USA), the bound conjugate was immunostained with 1,4-phenylenediamine and catechol (Merck, Darmstadt, FRG), as described (15).

Enzyme-linked immunosorbent (ELISA) assay conditions

The sandwich ELISA test for cathepsin B was performed as described (16). Cathepsin $\mathrm{H}$ was determined under the same conditions as described for the cathepsin B immunoassay. Anticathepsin $\mathrm{H} \mathrm{IgG}$ concentrations of $5 \mathrm{mg} / \mathrm{l}$ were used for coating; an optimal dilution of $1: 75$ of peroxidase-labelled anti-cathepsin $\mathrm{H} \mathrm{IgG} \mathrm{(17)} \mathrm{was} \mathrm{used} \mathrm{for} \mathrm{detection.}$

\section{Double sandwich ELISA test}

Microtitre plate wells (Nunc, Denmark) were coated with 0.5 $\mathrm{mg} / \mathrm{l}$ of sheep anti-cathepsin B IgG in $15 \mathrm{mmol} / \mathrm{l}$ carbonate buffer, $\mathrm{pH} 9.6$, overnight at $4{ }^{\circ} \mathrm{C}$. Thereafter the wells were

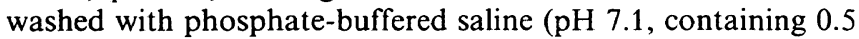
$\mathrm{g} / \mathrm{l}$ Tween 20 ), $0.1 \mathrm{ml}$ of the standard solutions or samples (sera and synovial fluids; diluted with phosphate buffered saline/ Tween containing $20 \mathrm{~g} / \mathrm{l}$ bovine serum albumin) were applied to each well, incubated for $2 \mathrm{~h}$ at $37^{\circ} \mathrm{C}$, and washed again after incubation. Then $0.1 \mathrm{ml}$ of rabbit anti-cathepsin B IgG solution ( $2 \mathrm{mg} / \mathrm{l}$ washing buffer containing bovine serum albumin) was added to each well and incubated again for $2 \mathrm{~h}$ at $37^{\circ} \mathrm{C}$. After washing, the bound rabbit antibodies were determined with goat antirabbit IgG peroxidase conjugate (dilution 1:10000) for $2 \mathrm{~h}$ at $37^{\circ} \mathrm{C}$. After washing with phosphate-buffered saline, $0.1 \mathrm{ml}$ of $0.1 \mathrm{~g} / 12,2^{\prime}$-azinobis(3-ethylbenzthiazoline sulphonic acid) solution and $0.12 \mathrm{~g} / \mathrm{l} \mathrm{H}_{2} \mathrm{O}_{2}$ solution in $0.01 \mathrm{~mol} / \mathrm{l}$ citrate phosphate buffer, $\mathrm{pH} 4.5$, was added to the wells and the absorbance measured at $410 \mathrm{~nm}$ (MinireaderII Dynatech, Denkendorf, FRG) after $30 \mathrm{~min}$ of incubation at $37^{\circ} \mathrm{C}$. Blanks, containing washing buffer instead of samples, were performed simultaneously.

Alternatively, 3,3',5,5' tetramethyl benzidine was used as the substrate for horseradish peroxidase conjugates, prepared as described (18).

\section{Results}

The specificities of the isolated anti-cathepsin B and $\mathrm{H}$ IgGs were proven by immunoblotting. The results are shown in figure 1. Isolated antibodies for cathepsin B reacted only with cathepsin B and showed no cross-reaction with cathepsin $\mathrm{H}$. Antibodies raised against cathepsin $\mathrm{H}$ were also immunospecific. No cross-reactivity was observed.

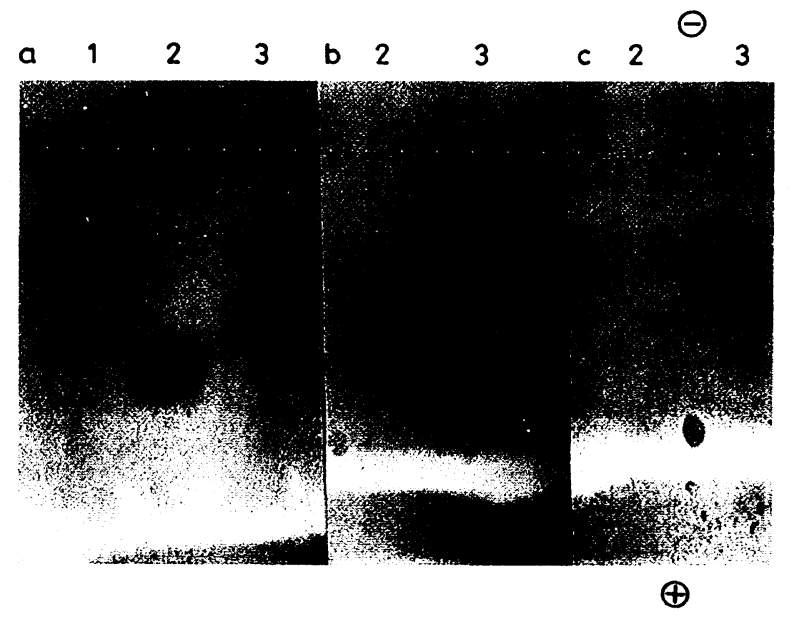

Fig. 1. Western blot analysis of cathepsins B and $\mathrm{H}$.

1) molecular weight standard,

2) cathepsin $B$

3) cathepsin $\mathrm{H}$

After transfer of proteins from SDS-PAGE, the blots were

a) stained with Amido black,

b) developed with anti-cathepsin B IgG,

c) developed with anti-cathepsin $\mathrm{H}$ IgG. 
In order to quantify the amounts of cathepsin B in normal sera, a more sensitive double sandwich ELISA test with a detection limit of $0.5 \mu \mathrm{g} / 1$ of antigen (fig. 2) was developed. The amount of cathepsin B found in normal sera ranged from $0.6 \mu \mathrm{g} / 1$ to $2 \mathrm{~g} / 1$ (mean value $0.96 \mu \mathrm{g} / \mathrm{l}$ with standard deviation of 0.36 , $\mathrm{n}=10$ ). Using the same test system the content of cathepsin B was measured in synovial fluids and sera (taken simultaneously) of patients with different joint diseases. Results are shown in table 1.

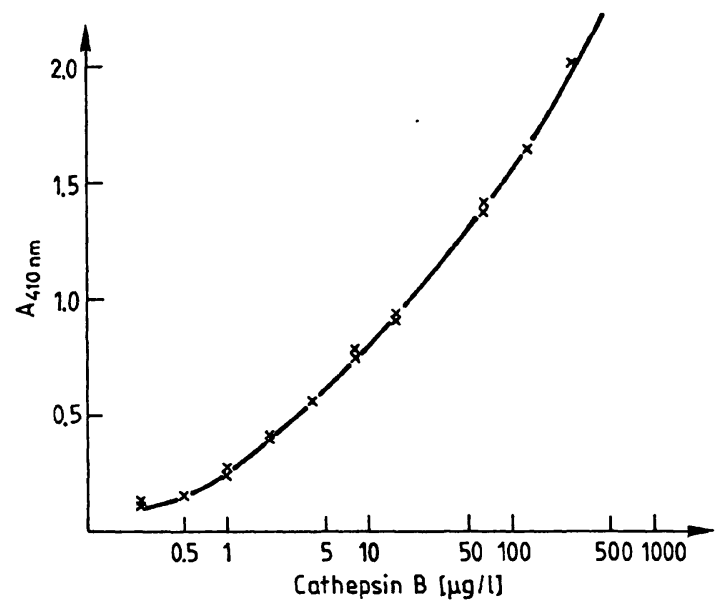

Fig. 2. Binding curve of cathepsin $B$ in the double sandwich ELISA for cathepsin B.

Tab. 1. Mean values of cathepsin B in synovial fluids and sera (taken simultaneously) of patients with different joint diseases. Others: gout (1), pseudogout (2), osteoarthritis (1).

\begin{tabular}{|c|c|c|c|c|c|}
\hline \multirow[t]{2}{*}{ Disease } & \multicolumn{3}{|c|}{ Serum } & \multicolumn{2}{|c|}{ Synovial fluid } \\
\hline & $\mathbf{n}$ & $\begin{array}{l}\overline{\mathrm{x}} \\
\mu \mathrm{g} / \mathrm{l}\end{array}$ & $\begin{array}{l}\text { range } \\
\mu \mathrm{g} / 1\end{array}$ & $\begin{array}{l}\overline{\mathrm{x}} \\
\mu \mathrm{g} / 1\end{array}$ & $\begin{array}{l}\text { range } \\
\mu \mathrm{g} / \mathrm{l}\end{array}$ \\
\hline $\begin{array}{l}\text { Rheumatoid } \\
\text { arthritis }\end{array}$ & 5 & 8.0 & $1.5-18$ & 49.2 & $\begin{array}{ll}17 & -89\end{array}$ \\
\hline $\begin{array}{l}\text { Seronegative } \\
\text { spondylarthritis }\end{array}$ & 2 & 3.0 & $2.4-3.5$ & 19.3 & $15.5-23$ \\
\hline $\begin{array}{l}\text { Undifferentiated } \\
\text { arthritis }\end{array}$ & 10 & 4.9 & $1.7-17$ & 36.3 & $10.8-78$ \\
\hline Others & 4 & 3.8 & $1.5-8.2$ & 24.8 & $27-39$ \\
\hline Normal sera & 10 & 0.96 & $0.6-2.0$ & & \\
\hline
\end{tabular}

Tab. 2. Mean values of cathepsin $\mathbf{H}$ determined in synovial fluids of patients with different joint diseases. Others: gout (1), pseudogout (1), osteoarthritis (1).

\begin{tabular}{lccc}
\hline Disease & $\mathrm{n}$ & \multicolumn{2}{c}{ Synovial fluid } \\
\cline { 2 - 4 } & & $\begin{array}{l}\mathrm{x} \\
\mu \mathrm{g} / 1\end{array}$ & \multicolumn{1}{l}{ range } \\
& $\mathrm{g} / \mathrm{l}$ \\
\hline Rheumatoid arthritis & 5 & 30.2 & $10-80$ \\
Seronegative spondylarthritis & 2 & 9.25 & $8-10.5$ \\
Undifferentiated arthritis & 8 & 44.7 & $11-120$ \\
Others & 3 & 9.9 & $7.8-12$ \\
\hline
\end{tabular}

Cathepsin $\mathrm{H}$ was determined in the same samples, which were used for cathepsin B determination, using the sandwich ELISA test (fig. 3). The amount of enzyme in normal sera was below the detection limit (below $3 \mu \mathrm{g} / \mathrm{l}$ ). The values for cathepsin $\mathrm{H}$ found in synovial fluids of the same patients, are shown in table 2 .

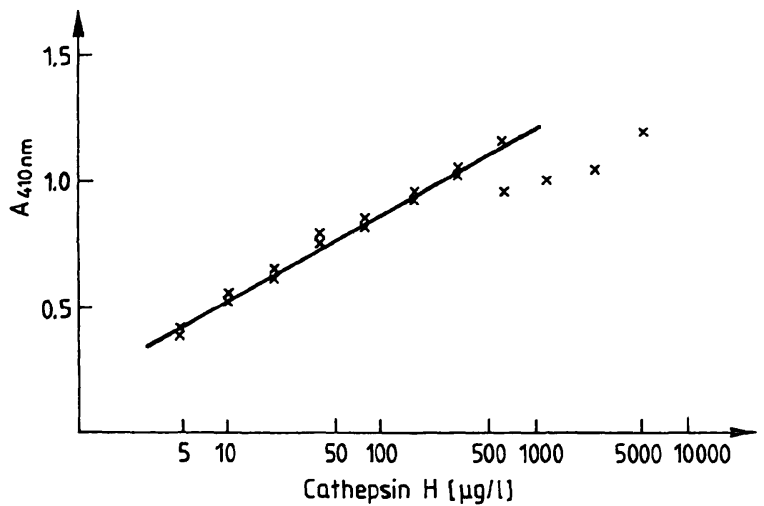

Fig. 3. Binding curve of cathepsin $\mathrm{H}$ in the sandwich ELISA for cathepsin $\mathrm{H}$.

Possible correlations between the content of cathepsins $B(n=17)$ and $H(n=15)$ and clinical data (synovial leukocytes, granulocytes and sedimentation rate) were studied. The values obtained for Pearson's correlation coefficients $(r)$ were in the range $0.05-$ 0.25 .

In order to examine whether the cathepsin B determined in different body fluids is present in a free or complexed form, cathepsin B was isolated from synovial fluid of patients with rheumatoid arthritis, using an anti-cathepsin $\mathrm{B}$ IgG immunoaffinity $\mathrm{CNBr}-\mathrm{Se}-$ pharose column. A SDS-PAGE of eluted cathepsin B after separation is shown in figure $4 \mathrm{a}$, indicating that

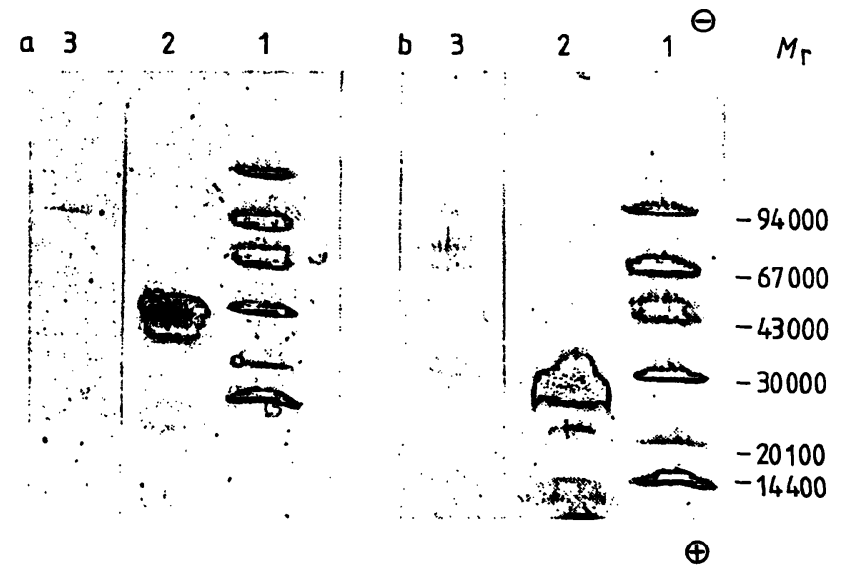

Fig. 4. SDS-PAGE of cathepsin B (3), isolated with anti-cathepsin B CNBr-Sepharose column from synovial fluid:

a) under nonreducing and

b) reducing conditions.

1) For comparison: relative molecular mass standards,

2) cathepsin B from human liver. 
cathepsin B in synovial fluid exists only in a complexed form and not as a free enzyme. Under reducing conditions this complex was dissociated into fragments with molecular weights of 67000,74000 and 96000 , as well as 29000 (fig. 4b). Using Western blot analysis, these proteins were identified as cathepsin B and kininogen (fig. 5).

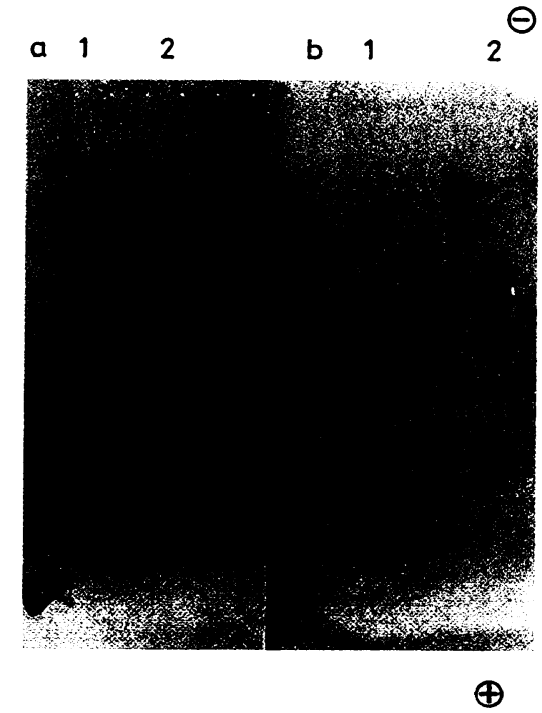

Fig. 5. Immunoblot of cathepsins after SDS-PAGE under reducing conditions.

1) Cathepsin $B$,

2) Cathepsin B from synovial fluid.

A: Blots developed with anti-cathepsin B IgG,

B: Blots developed with anti-kininogen IgG.

\section{Discussion}

It has been demonstrated that cathepsin $\mathrm{B}$ and $\mathrm{D}$ are present extracellularly in rheumatoid synovium. It was also shown that cathepsin $\mathrm{B}$, when released into the synovium, retains its initial enzyme activity up to

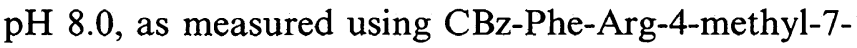
coumarylamide as a fluorescent substrate. The halflives of the enzyme at $\mathrm{pH} 7.5$ and 8.0 were found to be 7 minutes and 1.7 minutes, respectively (3).

In this work the development of enzyme immunoassays for cathepsins $B$ and $H$ made it possible to determine the amount of these two proteinases separately and specifically in different biological samples. Such immunological determination has an advantage when compared with enzyme activity assays, because the total amount of enzymes can be measured, regardless of whether they are free or in a complex with inhibitors (19). It was demonstrated that cathepsin B in synovial fluid was not detectable in a free form (fig. 4), but as complexes with proteins with a relative molecular mass between 67000 and 96000 . In Western blot analysis (fig. 5), strong immunoreaction was ob- served with antikininogen antibodies, proving that cathepsin B in synovial fluid was complexed with kininogen, a known inhibitor of cysteine proteinases (20). Kininogen and other cysteine proteinase inhibitors, present in synovial fluid, do not interfere in the immunological determination of cysteine proteinases as proved by Kominami (19).

Antibodies raised in rabbits against cathepsins B and $\mathrm{H}$ were specific and did not cross-react (fig. 1), proving that the antigens used in the present work were immunologically distinct, similar to cathepsins B and $\mathrm{H}$ from rat liver (21).

The double sandwich ELISA test could detect and measure $0.5 \mu \mathrm{g} / 1$ of cathepsin B (fig. 2), which is 10 times more sensitive than the previous measurement (16); in the case of cathepsin $\mathrm{H}$ the limit of detection was $3 \mu \mathrm{g} / 1$ (fig. 3). The high sensitivity of the assay for cathepsin B also enables the quantification of this enzyme in samples such as normal sera, which contain very small amounts $(0.96 \pm 0.36 \mathrm{~g} / \mathrm{l})$.

It is known that serum, plasma or blood in low dilutions may interfere with certain immunoassays, such as those for cortisol, progesterone or oestrogen (22). In our experiments, dilution of sera was not possible because of the limited amount of cathepsins in the sample. To prevent unspecific binding, a $20 \mathrm{~g} / \mathrm{l}$ bovine serum albumin solution was used. The values obtained for cathepsin B were in accordance with results published by Recklies \& Mort (23) using RIA.

In our assay, $\mathrm{pH} 7.1$ was used for the antigen-antibody reaction, which is close to the normal extracellular $\mathrm{pH}$ value; cathepsin $\mathrm{B}$ was rapidly enzymatically inactivated at this $\mathrm{pH}(24)$. It is known that the antisera raised against cathepsin $B$ tend to react only with the alkali-denaturated enzyme (25). Using assay conditions with alkali denaturation of the lysosomal enzyme, the total amount of cathepsin B was determined.

Different amounts for cathepsins $\mathrm{B}$ and $\mathrm{H}$ were determined in synovial fluids and sera from various diseased states (tabs. 1 and 2). The content of cathepsin $\mathrm{H}$ was in general lower than the content of cathepsin B. There were only three exceptions, all of them cases of undifferentiated arthritis. When blood and synovia were tested simultaneously, the values for cathepsin B showed a correlation, being clearly higher in synovial fluid. Patients with rheumatoid arthritis had on average a higher content of cathepsin $B$ in their synovial fluids and sera than other patients.

The highest values of cathepsin $\mathrm{H}$ were found in synovial fluids of patients with undifferentiated ar- 
thritis. Within each group of patients we found a wide range of values for both cathepsins. So far, no correlation has been observed between synovial leukocytes, granulocytes or sedimentation rate, and the amount of either enzyme. However, different factors can have an influence on the levels of cathepsins measured in biological samples, e. g. the clinical treatment, variations between individuals, and other diseases. Also rheumatoid factors have been reported to disturb certain types of sandwich assay (22).

\section{References}

1. Barrett, A. J. \& Kirschke, H. (1981) Cathepsin B, cathepsin $\mathrm{H}$ and cathepsin L. Methods Enzymol. 80, 535-561.

2. Turk, V., Brzin, J., Kopitar, M., Kotnik, M., Lenarčič, B., Popovič, T., Ritonja, A., Trstenjak, M., Rozman, B. \& Machleidt, W. (1986) Human cathepsin B, H and L and their enodgenous protein inhibitors: structure, function and biological role. In: Proteinases in Inflammation and Tumor Invasion (Tschesche, H. ed.) pp. 77-92, Walter de Gruyter Verlag, Berlin.

3. Mort, J. S., Recklies, A. D. \& Poole, A. R. (1984) Extracellular presence of the lysosomal proteinase cathepsin B in rheumatoid synovium and its activity at neutral $\mathrm{pH}$. Arth. Rheum. 27, 509-515.

4. Roughley, P. J. \& Barrett, A. J. (1977) The degradation of cartilage proteoglycans by tissue proteinases. Biochem. J. $167,629-637$.

5. Etherington, D. J. (1974) The purification of bovine cathepsin $B_{1}$ and its mode of action on bovine collagen. Biochem. J. 137, 387-398.

6. Isemura, M., Yosizava, Z., Takahashi, K., Kosaka, H., Kojima, N. \& Ono, T. (1981) Characterization of porcine plasma fibronectin and its fragmentation by porcine liver cathepsin B. J. Biochem. 90, 1 -9.

7. Zvonar, T., Kregar, I. \& Turk, V. (1980) Isolation of Cathepsin $\mathrm{B}$ and $\mathrm{N}$-benzoylarginine- $\alpha$-naphthylamide hydrolase from bovine lymph nodes. Croat. Chem. Acta 53, 509517.

8. Popovič, T., Brzin, J., Kos, J., Lenarčič, B., Machleidt, W., Ritonja, A., Hanada, K. \& Turk, V. (1988) A new purification procedure of human kidney cathepsin $\mathrm{H}$, its properties and kinetic data. Biol. Chem. Hoppe-Seyler 369, Suppl., 175-183.

9. Ropes, M. W., Bennett, G. A., Cobb, S., Jacox, R. \& Jessar, R. A. (1958) 1958 revision of diagnostic criteria for rheumatoid arthritis. Bull. Rheum. Dis. 9, 175-176.

10. Hadler, N. M., Johnson, A. M., Spitznagel, J. K. \& Quinet, R. J. (1981) Protease inhibitors in inflammatory synovial effusions. Ann. Rheum. Dis. 40, 55-59.

11. Laemmli, U. K. (1970) Cleavage of structural proteins during the assembly of the head of bacteriophage T4. Nature 227, 680-685.

12. Morton, B., Siegel, Y., Sinha, N. \& Vanderlaan, W. P. (1983) Production of antibodies by inoculation into lymph nodes. Methods Enzymol. 93, 3-12.

13. Ey, P. L., Prowse, S. J. and Jenkin, C. R. (1978) Isolation of pure $\operatorname{IgG}_{1}, \mathrm{IgG}_{2 \mathrm{a}}$ and $\mathrm{IgG}_{2 \mathrm{~b}}$ immunoglobulins from mouse serum using protein A-Sepharose. Immunochem. $15,429-436$.
As cartilage and bone damage in arthritis is thought to be caused primarily by an imbalance between active degrading enzymes and their specific inhibitors, which are secreted from the cells of the inflammed synovium, the quantification of each enzyme and inhibitor may be of clinical significance.

\section{Acknowledgement}

This work was supported and granted by the Research Council of Slovenia.

14. Towbin, H., Staehelin, T. \& Gordon, J. (1979) Electrophoretic transfer of proteins from polyacrylamide gels to nitrocellulose sheets: procedure and some applications. Proc. Natl. Acad. Sci. USA 76, 4350-4354.

15. Dziadek, M., Richter, H., Schachner, M. \& Timpl, R. (1983) Monoclonal antibodies used as probes for the structural organization of the central region of fibronectin. FEBS Lett. 155, $321-325$.

16. Lenarčič, B., Gabrijelčič, D., Rozman, B., Drobnič-Košorok, M. \& Turk, V. (1988) Human cathepsin B and cysteine proteinase inhibitors (CPIs) in inflammatory and metabolic joint diseases. Biol. Chem. Hoppe-Seyler 369, Suppl., $257-$ 261.

17. Carlson, J., Drevin, H. \& Axen, R. (1978) Protein thiolation and reversible protein-protein conjugation. N-Succinimidyl-3-(2-pyridyldithio)-propionate, a new bifunctional agent. Biochem. J. 173, 723-737.

18. Bos, E. S., Van der Doelan, A. A., Van Rooy, N. \& Schuurs, A. H. W. M. (1981) 3,3' 5,5'-Tetramethylbenzidine as an Ames test negative chromogen for horse-radish peroxidase in enzyme-immunoassay. J. Immunoassay 2, 187-204.

19. Kominami, E., Tsukahara, T., Bando, Y. \& Katunuma, N. (1985) Distribution of cathepsins $\mathrm{B}$ and $\mathrm{H}$ in rat tissues and peripheral blood cells. J. Biochem. 98, 87-93.

20. Mueller-Esterl, W., Fritz, H., Kellermann, J., Lottspeich, F., Machleidt, W. \& Turk, V. (1986) The mammalian cysteine proteinase inhibitors. Structural diversity and evolutionary origin. In: Cysteine Proteinases and Their Inhibitors (Turk, V., ed.) pp. 369-392, Walter de Gruyter Verlag, Berlin.

21. Kominami, E. \& Katunuma, N. (1982) Immunological studies on cathepsins $\mathrm{B}$ and $\mathrm{H}$ from rat liver. J. Biochem. 91, 67-71.

22. Shuurs, A. H. W. M. \& Weemen, B. K. (1977) Enzymeimmunoassay. Clin. Chim. Acta 81, 1-40.

23. Recklies, A. D. \& Mort, J. S. (1982) A radioimmunoassay for total human cathepsin B. Clin. Chim. Acta 123, 127138.

24. Machleidt, W., Ritonja, A., Popovič, T., Kotnik, M., Brzin, Turk, V., Machleidt, I. \& Mueller-Esterl, W. (1986) Human cathepsins $\mathrm{B}, \mathrm{H}$ and $\mathrm{L}$ : characterization by amino acid sequences and some kinetics of inhibition by kinonogens. In: Cysteine Proteinases and Their Inhibitors (Turk, V., ed.) pp. 3-18. Walter de Gruyter Verlag, Berlin.

25. Mort, J. S., Poole, A. R. \& Decker, R. S. (1981) Immunofluorescent localization of cathepsins $B$ and $D$ in human fibroblasts. J. Histochem. Cytochem. 29, 649-657.

Dr. Dušica Gabrijelčič

Department of Biochemistry

J. Stefan Institute

Jamova 39

Yu-61000 Ljubljana 
